\title{
Uptake of dissolved lead by anhydrite surfaces
}

\author{
Juan Morales $^{a}$, José Manuel Astilleros ${ }^{a, b, *}$, Amalia Jiménez ${ }^{c}$, Jörg Göttlicher ${ }^{d}$, Ralph Steininger ${ }^{d}$, \\ Lurdes Fernández-Díaz ${ }^{\mathrm{a}, \mathrm{b}}$
}

\footnotetext{
a Departamento de Cristalografía y Mineralogía, Universidad Complutense de Madrid, C/José Antonio Novais 2, Madrid 28040, Spain ${ }^{b}$ Instituto de Geociencias (CSIC, UCM), C/José Antonio Novais 2, Madrid 28040, Spain

${ }^{c}$ Departamento de Geología, Universidad de Oviedo, C/Jesús Arias de Velasco, Oviedo E-30005, Spain

${ }^{d}$ Karlsruher Institut für Technologie (KIT), Hermann-von-Helmholtz-Platz 1, D-76344 Eggenstein-Leopoldshafen, Germany
}

\section{A B S T R A C T}

The fate of harmful metals in the Earth crust is importantly affected by sorption processes on mineral surfaces. Here, a study of the ability of anhydrite surfaces to uptake dissolved $\mathrm{Pb}$ is presented. Experi-ments were conducted at room temperature using initial $\mathrm{Pb}$ concentration ([Pb $\left.\left.\mathrm{Pb}_{\mathrm{aq}}\right]_{0}\right)$ ranging between 10 and 1000 $\mathrm{mg} / \mathrm{L}$ and a batch type set-up. Inductively coupled plasma optical emission spectrometry analyses showed that $\left[\mathrm{Pb}_{\mathrm{aq}}\right]$ progressively decreased as the time of interaction increased, to reach a final steady state value of $\sim 3.0 \mathrm{mg} / \mathrm{L}$, irrespectively of $\left[\mathrm{Pb}_{\mathrm{aq}}\right] \mathrm{l}$. However, the time elapsed before the steady state value was reached strongly depended on $\left[\mathrm{Pb}_{\mathrm{aq}}\right]_{0}$, with the drop to this final value occurring in less than 1 day interaction when $\left[\mathrm{Pb} \mathrm{aq}_{0} \geq 50 \mathrm{mg} / \mathrm{L}\right.$ and after 20 days when $\left[\mathrm{Pb}_{\mathrm{aq}}\right]_{0}<50 \mathrm{mg} / \mathrm{L}$. Scanning Elec-tron Microscopy and X-ray diffraction analyses confirmed the epitactic growth of anglesite $\left(\mathrm{PbSO}_{4}\right)$ crys-tals on anhydrite surfaces when $\left[\mathrm{Pb}_{\mathrm{aq}}\right]_{0} \geq 50 \mathrm{mg} / \mathrm{L}$. X-ray Absorption Near Edge Structure spectroscopy points to a different sorption mechanisms when [Pbaq $]_{0}<50 \mathrm{mg} / \mathrm{L}$. The results show that the epitactic growth of anglesite on anhydrite has no significant impact on the ability of anhydrite surfaces to remove $\mathrm{Pb}_{\mathrm{aq}}$, which show equal effectiveness as that of gypsum surfaces. The high reactivity of anhydrite surfaces renders this phase potentially important in the control of the fate of dissolved metals in nature.

\section{Introduction}

Sorption processes occurring on mineral surfaces can be used to control the dissemination of inorganic contaminants as well as to safely storage them (Godelitsas and Astilleros, 2010; Hodson et al., 2000; O'Day and Vlassopoulos, 2010; Prieto et al., 2013). Among all sorption processes, co-precipitation is probably the most effective uptake mechanism. It frequently involves the dissolution of the sorbant (or substrate) followed by the formation of insoluble sorbate nuclei and crystals directly on the sorbant sur-face. However, the efficiency of this mechanisms in the removal of pollutants may be drastically reduced by the existence of epitactic relations between sorbent and sorbate. Under certain unfavourable conditions, the surface of the sorbant can become rapidly passiv-ated due to the growth of a continuous epitactic layer of the sor-bate thereby, becoming inefficient to further uptake the pollutant (Prieto et al., 2003; Rodríguez-Blanco et al., 2007). For example, Cd can be removed from solution by co-precipitation of otavite $\left(\mathrm{CdCO}_{3}\right)$ on both calcite and aragonite surfaces. However, it has been shown that the capacity of calcite to uptake $\mathrm{Cd}$ is

\footnotetext{
* Corresponding author at: Departamento de Cristalografía y Mineralogía, . Tel.: +34 913944881 .

E-mail address: jmastill@ucm.es (J.M. Astilleros).
}

considerably lower than showed by aragonite (Prieto et al., 2003). This is a direct consequence of otavite being isostructural with calcite, which favors the formation of a nanometric homogeneous otavite layer that armors calcite surfaces and leads to the complete halt of Cd removal (Pérez-Garrido et al., 2007). In contrast, the formation of otavite nuclei randomly oriented on aragonite guarantees the progress of the Cd uptake.

Among sedimentary rock-forming minerals, calcium sulfates, and more specifically gypsum $\left(\mathrm{CaSO}_{4} \cdot 2 \mathrm{H}_{2} \mathrm{O}\right)$ and anhydrite $\left(\mathrm{CaSO}_{4}\right)$, emerge as potentially useful minerals to take up, via dissolutionprecipitation mechanisms, dissolved metals. Indeed, Astilleros et al. (2010), investigating the uptake of $\mathrm{Pb}$ by gypsum $\left(\mathrm{K}_{\mathrm{sp}}=10^{-4.48}\right)$, concluded that this mineral has a remarkable capac-ity to remove $\mathrm{Pb}_{(\mathrm{aq})}$ from highly contaminated aqueous solutions via the formation of the solid phase anglesite $\left(\mathrm{PbSO}_{4}\right)$. A close inspec-tion of the gypsum surfaces evidenced that anglesite crystals are located in a random orientation with respect to the gypsum sub-strate. As a consequence, the contact between the aqueous solution and the gypsum surface is always maintained, guaranteeing the progress of the dissolution-crystallization process with time.

Anhydrite $\left(\mathrm{CaSO}_{4}\right)$ is the second most abundant sulfate mineral in surface and subsurface Earth environments (Sharpe and Cork, 2006; Tucker, 2001). The solubility product of anhydrite $\left(K_{s p}=10^{-4.36}\right)$ is close to that of gypsum, being slightly higher at temperatures below $58{ }^{\circ} \mathrm{C}$ and lower at higher temperatures 
(Freyer and Voigt, 2003). Therefore, taking into account physicochemical factors only, it can be expected that at low temperatures anhydrite can eventually become as effective as gypsum to uptake $\mathrm{Pb}$. However, in a detailed study Morales et al. (2013) has shown that anglesite grows epictactically on the most important anhydrite surfaces. This fact might compromise the ability of this phase to uptake $\mathrm{Pb}$, in a similar way as occurs with calcite ability to uptake $\mathrm{Cd}$.

In this work we evaluate the uptake effectiveness of anhydrite crystals as $\mathrm{Pb}$-sequester. The results are compared to those obtained in experiments carried out using gypsum crystals as sorbent (Astilleros et al., 2010). We pay special attention to the possible effect of the spatial arrangement of the sorbate on the sorbant on the progress of the uptake phenomena, aiming to extract general conclusions on the capability of anhydrite surfaces to uptake dissolved $\mathrm{Pb}$ and contribute to draw a more complete picture of the fate of dissolved $\mathrm{Pb}$ in natural environments.

\section{Epitactic overgrowth of anglesite on anhydrite surfaces}

Anhydrite and anglesite are sulfates with different but related structures. Both are orthorhombic and their structures are based on chains of alternating edge-sharing $\left(\mathrm{SO}_{4}\right)$ tetrahedra and [n]coordination polyhedra that are linked into a framework. Moreover, the $\mathrm{a}$ and $\mathrm{b}$ cell parameters of anhydrite $(6.993 \AA$ and $6.995 \AA$, respectively) are very close to the $c$ cell parameter in anglesite (c = $6.958 \AA$ ). These similarities in both structure and cell parameters encourages a priori the development of epitactic growth. On the basis of these premises, Morales et al. (2013) con-ducted a systematic study of the possible epitactic relations exist-ing between these phases, focusing on the three main forms in the habit of anhydrite crystals, the pinacoids $\left\{\begin{array}{lll}1 & 0 & 0\end{array}\right\},\left\{\begin{array}{lll}0 & 0 & 1\end{array}\right\}$, and $\left\{\begin{array}{lll}0 & 1 & 0\end{array}\right\}$. This study yielded results which are particularly timely to mention here: (1) As expected, oriented anglesite crystals grow epitactically on all anhydrite surfaces investigated. (2) The density of oriented anglesite varies widely from one substrate to another: a high den-sity anglesite crystals was observed on $\left\{\begin{array}{lll}0 & 0 & 1\end{array}\right\}_{\text {Anh }}$, but a significantly lower number of anglesite were observed to form on $\left\{\begin{array}{ll}10 & 0\end{array}\right\}_{\mathrm{Anh}}$ and $\left\{\begin{array}{lll}0 & 1 & 0\end{array}\right\}_{\mathrm{Anh}}$. (3) Anglesite overgrowth does not consist of nanometric 2D layers completely covering the anhydrite surface as those ob-served in other systems (Pérez-Garrido et al., 2007, 2009) but rather of isolated idiomorphic crystals exhibiting nearly tabular to blocky habits that upon growth can eventually coalesce. These crystals are micrometer-sized and can be observed under relatively low magnification (i.e. using an optical microscope).

\section{Experimental methods}

Uptake experiments were carried out by reacting single-phase natural anhydrite crystals from Naica (Chihuahua, Mexico) with $\mathrm{Pb}$ bearing aqueous solutions. The crystals were crushed using a mechanic agate mortar (RETSCH-RM100). Fragments containing visible impurities (under magnification $25 \times$ ) were removed. The remaining grains were ultrasonically cleaned in an ethanol bath, thoroughly rinsed with deionized water and sieved to the selected size range (1-1.6 $\mathrm{mm})$. The anhydrite samples were probed as highly pure (less than 0.4 wt\% impurities) by X-ray Fluorescence Spectroscopy analysis (XRF-PANalytical Avios). The Pb-aqueous solutions used in the experiments were prepared adding reagentgrade $\mathrm{Pb}\left(\mathrm{NO}_{3}\right)_{2}$ (Fluka) to high-purity de-ionized water (resistivity $18.2 \mathrm{MO} \mathrm{cm})$ to reach an initial $\mathrm{Pb}$ concentration $\left(\left[\mathrm{Pb}_{\mathrm{aq}}\right]_{0}\right)$ of 10,50 100 and $1000 \mathrm{mg} / \mathrm{L}\left(\mathrm{pH}_{\text {initial }}=6.80-4.75\right)$. In all cases, $2.00 \pm 0.005 \mathrm{~g}$ of mineral grains with diameters in the range $1-1.6 \mathrm{~mm}$ were added to polypropylene vessels containing $100 \mathrm{~mL}$ of continuously stirred $\mathrm{Pb}\left(\mathrm{NO}_{3}\right)_{2}$ aqueous solution. The stirring rate was adjusted to 300 $\mathrm{rpm}$. The reactors were immediately sealed with a cover and maintained in a temperature controlled $\left(25 \pm 0.5^{\circ} \mathrm{C}\right)$ laboratory cabinet. For each initial solution composition (10, 50, 100 and 1000 $\mathrm{mg} / \mathrm{L}$ ) independent experimental runs were conducted and terminated after increasing reaction times, ranging from $1 \mathrm{~min}$ to 5 weeks. Each run was carried out in triplicate. The solid and liquid phases were sampled to follow the physicochemical evolution of the system. Sampled solutions were filtered through a $0.45 \mathrm{Im}$ Mil-lipore filter and analyzed using inductively coupled plasma optical emission spectrometry (ICP-OES). Data obtained from chemical analyses were used to calculate activities of metal ions and satura-tion indices (SI) with respect to relevant solid phases using the geo-chemical code and database PHREEQC (Parkhurst and Appelo, 1999). Sampled anhydrite fragments were washed with Milli-Q water to remove excess salts, subsequently rinsed with ethanol and dried at room temperature. The surface of the anhydrite crys-tals was imaged by means of a Scanning Electron Microscope (SEM, JEOL JSM 6400). Energy-dispersive X-ray spectroscopy (EDX) analyses (Oxford Instruments) were carried out on selected areas of the surface of the anhydrite samples. Powder X-ray diffrac-tion analysis (PANalytical X'Pert MPD equipped with a $\mathrm{Cu}$ Ka X-ray source) allowed us to identify the solid phase(s) formed on anhy-drite crystal surfaces. Aiming to complete the characterization of the possible Pb-uptake processes occurring on anhydrite crystals, freshly cleaved surfaces of anhydrite were put in contact with $5 \mathrm{~mL}$ of solutions with a $\left[\mathrm{Pb}_{\mathrm{aq}}\right]_{0}$ of 10 and $1000 \mathrm{mg} / \mathrm{L}$. The interac-tion lasted 1 week and $2 \mathrm{~h}$, respectively. Three different cleavage surfaces, $\left(\begin{array}{lll}1 & 0 & 0\end{array}\right),\left(\begin{array}{lll}0 & 0\end{array}\right)$ and $\left(\begin{array}{l}0 \\ 0\end{array}\right.$ 0 1) were considered. The average ex-posed area was $\sim 15 \mathrm{~mm}^{2}$. These samples were imaged using SEM and further studied using the X-ray beamline of the Synchrotron Radiation Laboratory for Environmental Studies (SUL-X) at the synchrotron radiation source ANKA of the Karlsruhe Institute of Technology (ANKA Instrumentation Book, 2011) by means of micro X-ray fluorescence spectroscopy (I$X R F$ ) in combination with X-ray Absorption Near Edge Structure (XANES) spectroscopy. Synchrotron radiation at the SUL-X beamline is generated from a wiggler. As monochromator (fixed exit) a $\mathrm{Si}(111)$ crystal pair is used. Final focusing is done with a Kirck Patrick Baez Mirror. $\mathrm{Pb}$ elemental dis-tribution have been measured at different anhydrite crystal faces by exciting the $\mathrm{Pb} \mathrm{L}_{a}$ fluorescence emission at $13.4 \mathrm{keV}$ and detecting it with a 7 element $\mathrm{Si}(\mathrm{Li})$ solid state detector (Gresham, now SGX Sen-sortech) by integrating the Pb La emission within 10,190 an 10,630 eV. Beamsize at sample position was about $70 \times 70 \mu^{2}$. The sample has been mapped with horizontal and vertical step widths of $50 \mathrm{Im}$ at $5 \mathrm{~s}$ counting time. Homogeneous areas have been selected to measure $\mathrm{Pb} \mathrm{L}_{\alpha}$ XANES spectra with a beamsize of about $200 \times 200{\mu \mathrm{m}^{2}}^{2}$ in fluorescence mode collecting the $\mathrm{Pb} \mathrm{L}_{\mathrm{a}}$ fluorescence emission as a function of incident energy again with the 7 element $\mathrm{Si}(\mathrm{Li})$ solid state detector. Energy step widths across the absorption edges were $0.5 \mathrm{eV}$. The sample surface has been ad-justed $45^{\circ}$ to the incoming beam, the angle between beam and detector is $90^{\circ}$. To reduce orientation effects spectra were measured every $30^{\circ}$ rotating the sample in its surface normal, and averaged. Energy was calibrated to the maximum of the derivative of the inflection point at $13,035 \mathrm{eV}$ using a $\mathrm{Pb}$ metal foil. From analytical grade $\mathrm{PbSO}_{4}$ (anglesite) a reference spectrum has been recorded in order to identify precipitations of anglesite on anhydrite surfaces. Data processing of the XANES spectra were done by the Athena software (Ravel and Newville, 2005).

\section{Results}

\subsection{Macroscopic experiments in batch reactors}

In all the experiments the interaction between anhydrite crys-tals and $\mathrm{Pb}$-bearing solutions lead to a significant removal of this 
pollutant, which occurred at different rates depending on $\left[\mathrm{Pb}_{\mathrm{aq}}\right]_{0}$. Fig. 1 shows the evolution of $\mathrm{Pb}, \mathrm{SO}_{4}$ and $\mathrm{Ca}$ concentrations as a function of time for the interaction experiments performed using aqueous solutions with $\left[\mathrm{Pb}_{\mathrm{aq}}\right]_{0}$ ranging from 10 to $1000 \mathrm{mg} / \mathrm{L}$. When $\left[\mathrm{Pb}_{\mathrm{aq}}\right]_{0}>$ $50 \mathrm{mg} / \mathrm{L}$, the evolution of the $\mathrm{Pb}$ content was char-acterized by a dramatic drop during the first minutes of the inter-action to reach an asymptotic value before $24 \mathrm{~h}$ (see Fig. 1a-c). Fig. 1a depicts this evolution for aqueous solutions with $\left[\mathrm{Pb}_{\mathrm{aq}}\right]_{0}=1000 \mathrm{mg} / \mathrm{L}$. In this case, the intense removal of $\mathrm{Pb}$ during the early minutes of the interaction determined the drop of the $\mathrm{Pb}$ content to approximately a half of $\left[\mathrm{Pb}_{\mathrm{aq}}\right]_{0}(465 \mathrm{mg} / \mathrm{L})$ after $1 \mathrm{~h}$ of interaction. The $\mathrm{Pb}$ content in the solution reached $\sim 0.56 \%$ of $\left[\mathrm{Pb}_{\mathrm{aq}}\right]_{0}$ after only $6 \mathrm{~h}$ of interaction $\left(\left[\mathrm{Pb}_{\mathrm{aq}}\right]_{\mathrm{Gh}} \approx 5.6 \mathrm{mg} / \mathrm{L}\right)$. Similarly, when solutions with $\left[\mathrm{Pb}_{\mathrm{aq}}\right]_{0}=100 \mathrm{mg} /$ $\mathrm{L}$ were used (Fig. $1 \mathrm{~b}$ ) the ini-tial $\mathrm{Pb}$ content rapidly decreased to a $\left[\mathrm{Pb}_{\mathrm{aq}}\right]=9.5 \mathrm{mg} / \mathrm{L}$ (approxi-mately $10 \%\left[\mathrm{~Pb}_{\mathrm{aq}}\right]_{0}$ ) after an elapsed time of $1 \mathrm{~h}$, reaching a concentration of $\sim 4.5 \mathrm{mg} / \mathrm{L}$ after $6 \mathrm{~h}$. When solutions with $\left[\mathrm{Pb}_{\mathrm{aq}}\right]_{0}=50 \mathrm{mg} / \mathrm{L}$ were used, the evolution of $\mathrm{Pb}$ concentration also followed a similar trend (Fig. 1c). After the first hour of interaction the $\mathrm{Pb}$ content decreased to $\mathrm{a}\left[\mathrm{Pb}_{\mathrm{aq}}\right]=7.1 \mathrm{mg} / \mathrm{L}$ (approximately $14 \%\left[\mathrm{~Pb}_{\mathrm{aq}}\right]_{0}$ ), and a value of $\left[\mathrm{Pb}_{\mathrm{aq}}\right]_{\mathrm{ch}} \approx 4.8 \mathrm{mg} / \mathrm{L}$ is reached after $6 \mathrm{~h}$. In the three cases, the solution $\mathrm{Pb}$ content reached an asymptotic va-lue of $\sim 3.0 \mathrm{mg} / \mathrm{L}$ within the first $24 \mathrm{~h}$.

In contrast, the behavior observed in the experiments using solutions with $\left[\mathrm{Pb}_{\mathrm{aq}}\right]_{0}=10 \mathrm{mg} / \mathrm{L}$ differs from the described above, with $\left[\mathrm{Pb}_{\mathrm{aq}}\right]$ dropping at a much slower rate (Fig. 1d). In this case only a $10 \%$ of the initial $\mathrm{Pb}$ content was removed in the first $24 \mathrm{~h}\left(\left[\mathrm{~Pb}_{\mathrm{aq}}\right]_{24 \mathrm{~h}} \approx\right.$ $9.0 \mathrm{mg} / \mathrm{L})$. After 1 week, the $\mathrm{Pb}$ content was $\sim 5.7 \mathrm{mg} / \mathrm{L}$, decreasing progressively at slower rate to finally reach an asymptotic value close to $3.0 \mathrm{mg} / \mathrm{L}$ after $\sim 20$ days.

The changes in $\mathrm{pH}$ are small, which supports that any signifi-cant effect of this parameter on changing the chemical speciation of the solution can be neglected. It is worth to note that after
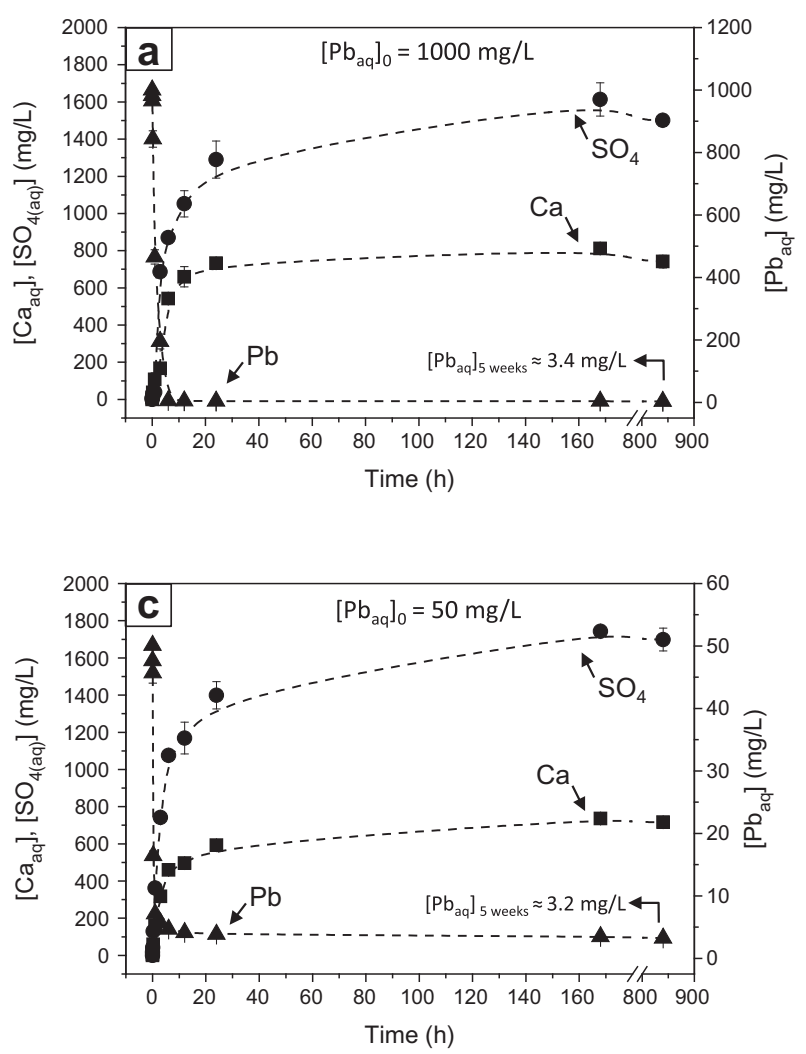

prolonged reaction times an almost identical final $\mathrm{Pb}$ content $\left(\left[\mathrm{Pb}_{\mathrm{aq}}\right]_{1}\right.$ $\approx 3 \mathrm{mg} / \mathrm{L}$ ) was attained, irrespective the initial $\mathrm{Pb}$ concen-tration in the solution.

As mentioned above, Fig. 1 also shows the evolution of the concentrations of $\mathrm{Ca}$ and $\mathrm{SO}_{4}$ in the solutions as a function of time. It is assumed that when experiments started $(\mathrm{t}=0)$ the aqueous solutions were virtually free of $\mathrm{Ca}$ and $\mathrm{SO}_{4}$. However, as soon as anhydrite fragments were put in contact with $\mathrm{Pb}$-bearing solutions, their dissolution immediately started, releasing $\mathrm{Ca}$ and $\mathrm{SO}_{4}$ to the solution. The evolution of $\mathrm{Ca}$ and $\mathrm{SO}_{4}$ concentration followed a similar trend in all the experiments carried out. As can be observed, the concentration of both $\mathrm{Ca}$ and $\mathrm{SO}_{4}$ increased rapidly during the initial minutes of the experiment to reach an asymptotic value for prolonged reaction times. This asymptotic value differed depending on the initial $\mathrm{Pb}$ content in the solution. In the case of all the experiments conducted using $\left[\mathrm{Pb}_{\mathrm{aq}}\right]_{0} \geq 50 \mathrm{mg} / \mathrm{L}$, the evolution of $\mathrm{Ca}$ and $\mathrm{SO}_{4}$ concentrations correlates with the decrease of the $\mathrm{Pb}$ concentration as the interaction progresses. Moreover, the evolu-tion of the concentration of $\mathrm{Ca}$ and $\mathrm{SO}_{4}$ depends on $\left[\mathrm{Pb}_{\mathrm{aq}}\right]_{0}$. For low concentrated $\mathrm{Pb}$-bearing solutions $\left(\left[\mathrm{Pb}_{\mathrm{aq}}\right]_{0}=10 \mathrm{mg} / \mathrm{L}\right)$, the amount of $\mathrm{Ca}$ and $\mathrm{SO}_{4}$ was always similar during the whole reac-tion process (1615 and $676 \mathrm{mg} / \mathrm{L}$, respectively for $\mathrm{t}=1$, equivalent to 16.9 and $16.8 \mathrm{mmol} / \mathrm{L})$. However, when more concentrated solu-tions $\left(\left[\mathrm{Pb}_{\mathrm{aq}}\right]_{0}\right.$ $\geq 50 \mathrm{mg} / \mathrm{L}$ ) were used, the difference between the values of $\left[\mathrm{SO}_{4}\right]$ and $[\mathrm{Ca}$ ] changes markedly with time. This differ-ence is more pronounced in those experiments carried out using the most concentrated $\mathrm{Pb}$-solutions $\left(\left[\mathrm{Pb}_{\mathrm{aq}}\right]_{0}=1000 \mathrm{mg} / \mathrm{L}\right.$; see Fig. 1a), where the distance between the $[\mathrm{Ca}]$ and $\left[\mathrm{SO}_{4}\right]$ curves is shorter.

The results for $\left[\mathrm{Pb}_{\mathrm{aq}}\right]_{0} \geq 50 \mathrm{mg} / \mathrm{L}$ point to a coupling between anhydrite dissolution and $\mathrm{Pb}$ uptake through an anglesite nucle-ation and growth process. A different behavior is, however, ob-served when $\left[\mathrm{Pb}_{\mathrm{aq}}\right]_{0}=10 \mathrm{mg} / \mathrm{L}$ (Fig. 1d), where the rapid release


Fig. 1. Evolution of $\mathrm{Pb}, \mathrm{SO}_{4}$ and $\mathrm{Ca}$ concentrations (from ICP-OES analyses) during the interaction of anhydrite with $\mathrm{Pb}-\mathrm{bearing}$ aqueous solutions. (a) $[\mathrm{Pb} \text { aq }]_{0}=1000$, (b) 100 , (c) 50 and (d) $10 \mathrm{mg} / \mathrm{L}$. 
of $\mathrm{Ca}$ and $\mathrm{SO}_{4}$ to the aqueous solution does not clearly correlate with the slow decrease of the $\mathrm{Pb}$ concentration. The differences be-tween the final $\mathrm{Ca}, \mathrm{SO}_{4}$ and $\mathrm{Pb}$ concentrations will be discussed in the correspondent section.

\subsection{Characterization of the solids}

When aqueous solutions with $\left[\mathrm{Pb}_{\mathrm{aq}}\right]_{0} \geq 50 \mathrm{mg} / \mathrm{L}$ were used, sol-ids were observed to form on the surface of the anhydrite frag-ments. Moreover, when $\left[\mathrm{Pb}_{\mathrm{aq}}\right]_{0}=1000 \mathrm{mg} / \mathrm{L}$, during the first minutes of the interaction the solutions turned cloudy and whitish, which can be interpreted as the result of a precipitation reaction occurring in the bulk. XRD analyses conducted on this powder col-lected by filtering the aqueous solution exclusively consisted of anglesite. SEM observations of anhydrite surfaces after different interaction periods evidence that the newly formed solid consists of idiomorphic crystals (Fig. 2). In most surfaces such crystals grew oriented on anhydrite, evidencing the existence of epitaxial rela-tionships between both phases. The oriented distribution of these crystals on anhydrite is clearly illustrated in Fig. $2 a$ and b. Both the orientation and the habit exhibited by these crystals are very similar to the anglesite crystals formed onto the faces of the $\left\{\begin{array}{ll}0 & 01\end{array}\right\}$ anhydrite form (Morales et al., 2013). The composition of these crystals differs from that of anhydrite as shown by their higher brightness in back-scattered electron images (Fig. 2c). EDX analyses carried out on these crystals provided a composition con-sistent with anglesite (see Fig. 2d). Moreover, Powder XRD patterns obtained for short interaction times $(24 \mathrm{~h})$ on anhydrite fragments further confirmed the newly formed solid as anglesite (Fig. 3a). In addition, for longer interaction times gypsum was always distin-guishable in the X-ray diffraction diagrams and/or the SEM images, independently of the initial $\mathrm{Pb}$ concentration (Fig. $3 b)$. It is impor-tant to note that SEM imaging of anhydrite surfaces interacted with aqueous solutions containing the lowest $\mathrm{Pb}$ concentrations $\left(\left[\mathrm{Pb}_{\mathrm{aq}}\right]_{0}=10 \mathrm{mg} / \mathrm{L}\right)$ did not evidenced the formation of anglesite crystals.

In order to check possible differences in $\mathrm{Pb}$ uptake capacity by different anhydrite surfaces, selected samples of anhydrite surfaces cleaved parallel to $\left(\begin{array}{lll}1 & 0 & 0\end{array}\right),\left(\begin{array}{ll}0 & 0\end{array}\right)$ and $\left(\begin{array}{ll}0 & 01\end{array}\right)$ interacted during 1 week with solutions with $\left[\mathrm{Pb}_{\mathrm{aq}}\right]_{0}=10 \mathrm{mg} / \mathrm{L}$ were studied by $\mathrm{I}-\mathrm{XRF} . \mathrm{Pb}$ elemental distribution on these surfaces evidence a higher reactivity of (00 1), which appears as the surface with highest $\mathrm{Pb}$ uptake capability followed by $(010)$ surface. In Fig. 4 Pb-distribu-tion maps corresponding to (001) (Fig. 4a), (01 0) (Fig. 4b) and (001) (Fig. 4c) surfaces are compared. In Fig. 5 the features of the $\mathrm{Pb} \mathrm{L}_{3}$ XANES spectra recorded on the $(001)$ and $(100)$ (Fig. $5 b$ and c) surfaces of the runs with high $\mathrm{Pb}$ concentrations $(1000 \mathrm{mg} / \mathrm{L})$ are in good agreement with a reference spectrum of $\mathrm{PbSO}_{4}$ (anglesite) (Fig. 5a), further confirming that when aqueous solutions with $\left[\mathrm{Pb}_{\mathrm{aq}}\right]_{0} \geq 50 \mathrm{mg} / \mathrm{L}$ are used, $\mathrm{Pb}$ sorption on anhy-drite surfaces mainly occurs via formation of anglesite.

However, the XANES spectra measured on anhydrite $\left(\begin{array}{lll}1 & 0 & 0\end{array}\right),\left(\begin{array}{ll}0 & 1\end{array}\right.$ $0)$ and $(001)$ surfaces after 1 week interaction with aqueous solutions with $\left[\mathrm{Pb}_{\mathrm{aq}}\right]_{0}=10 \mathrm{mg} / \mathrm{L}$ show features which do not agree with those characteristic for anglesite. Fig. $5 \mathrm{~d}$ shows the average of 7 from 12 spectra that were recorded every $30^{\circ}$ rotating around the surface normal from the $\left(\begin{array}{l}0 \\ 01\end{array}\right)$ crystal face. Averaging was possible for the 7 spectra because they match well whereas for the remain-ing 5 spectra edge shape and positions vary (Fig. 6). In the averaged spectrum (Fig. 5) the characteristic hump in the anglesite spectra at about $13,062 \mathrm{eV}$ is not visible. The position for the main hump behind the edge is shifted from about $13,076.5 \mathrm{eV}$ (anglesite) to about 13,084 eV (low Pb, ( $\left.\begin{array}{lll}1 & 0 & 0\end{array}\right)$ face, 7 spectra averaged). For the other 5 spectra a double hump feature similar to the anglesite spectra can be recognized to some extent (Fig. 6). One explanation might be that non-ideally flat surfaces gives opportunities for small amounts of anglesite crystal formation in, e.g., periodically ar-ranged grooves (Fig. 7), and due to the $45 / 90^{\circ}$ beam/sample/detec-tor measurement geometry for about $180^{\circ}$ of rotation fluorescence radiation from these anglesite crystals reaches the detector and mixes with the signals from $\mathrm{Pb}$ adsorbed on the surfaces. This would also explain the higher net count rates for such spectra be-cause $\mathrm{Pb}$ concentration in anglesite is most probably higher than $\mathrm{Pb}$ adsorbed on surfaces related to the same irradiated sample vol-ume (spectra a-e in Fig. 6 that cluster in one half of the sample rotation angles).
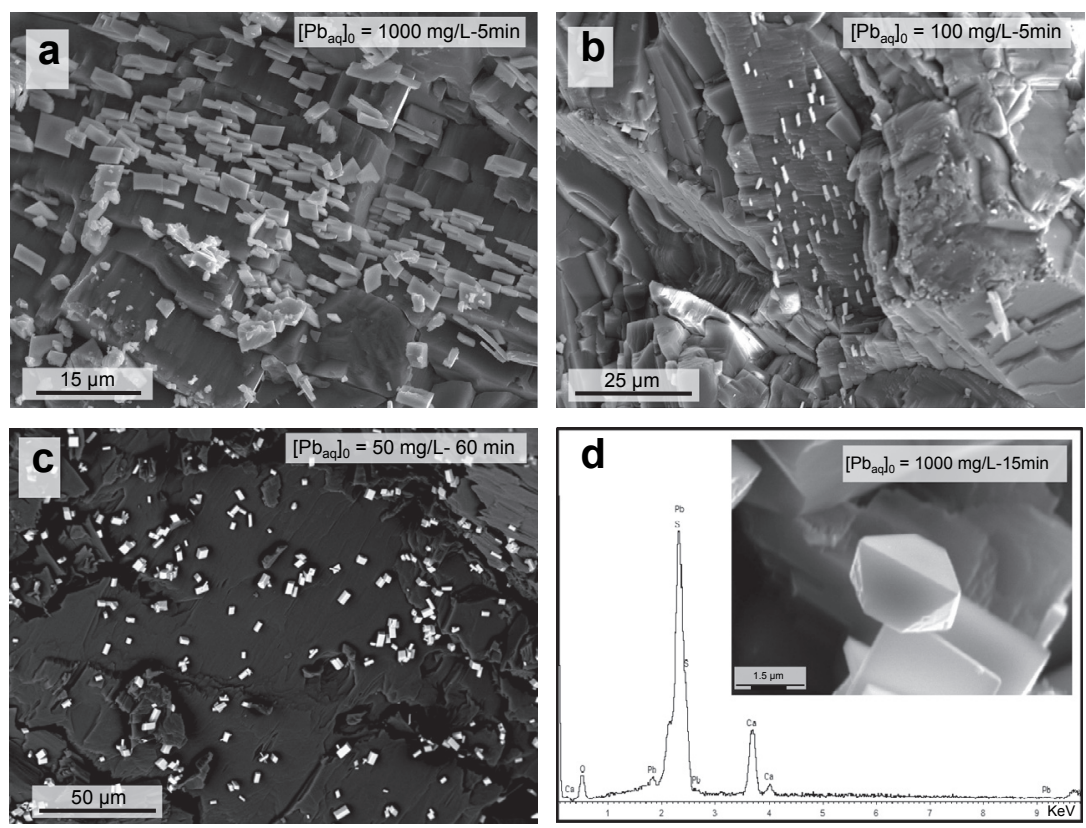

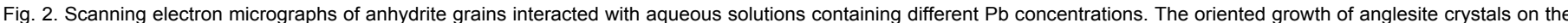

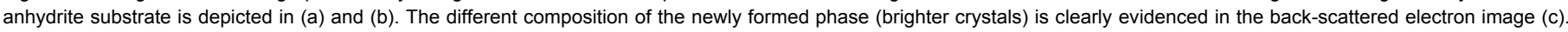
EDX analyses confirmed that the new phase has a high content of $\mathrm{Pb}(\mathrm{d})$. 

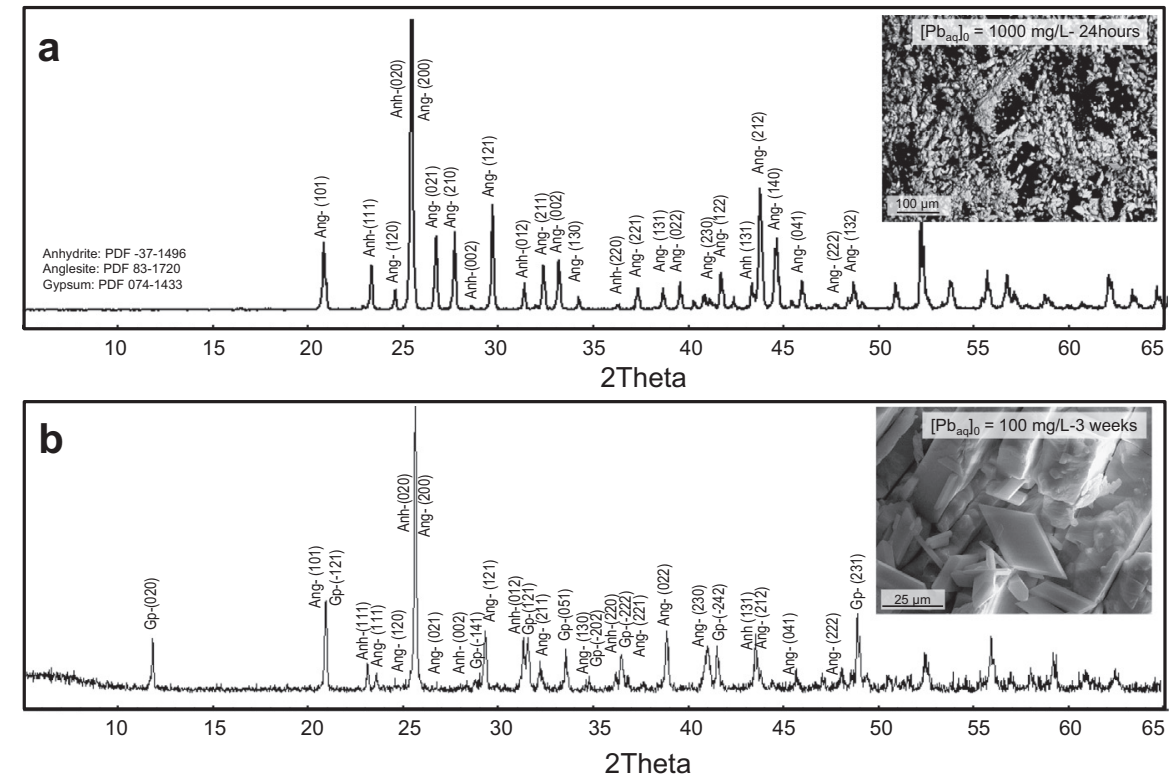

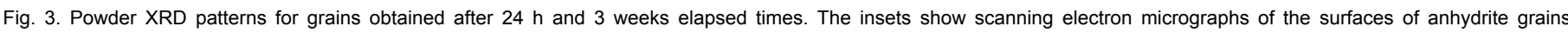

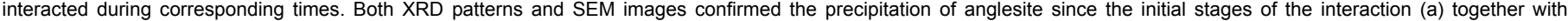
gypsum after prolonged interaction times (b).
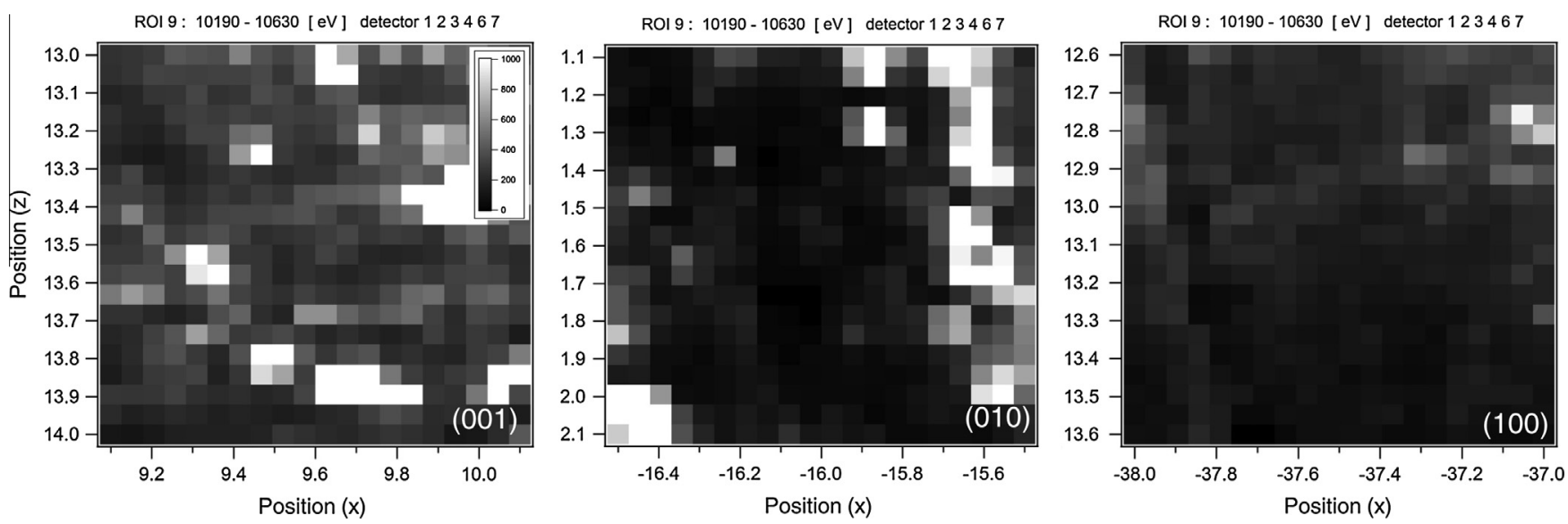

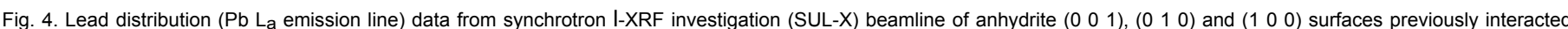

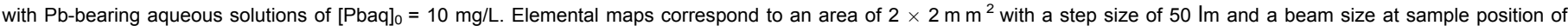
about $70 \times 70 \mathrm{Im}^{2}$.

\section{Discussion}

The experimental results described in the previous section indicate that the interaction of $\mathrm{Pb}$-bearing aqueous solutions with anhydrite leads to the dissolution of anhydrite crystals, shortly followed by the precipitation of anglesite. The formation of anglesite on the surface of the dissolving anhydrite crystals has been clearly evidenced by SEM observations in the experiments conducted using aqueous solutions with $\left[\mathrm{Pb}_{\mathrm{aq}}\right]_{0} \geq 50 \mathrm{mg} / \mathrm{L}$. Anhydrite disso-lution and anglesite precipitation seem to be coupled processes, according to the evolution of the aqueous solution SI with respect to the relevant solid phases (anhydrite, present in the system when the experiment starts, gypsum, which is the stable phase of $\mathrm{CaSO}_{4}$ under the prevailing experimental conditions, and anglesite, the precipitating phase) as the interaction proceeds. This evolution is shown in Fig. 8, where the aqueous solution SIs with respect to these three phases are plotted against time. The $S I$ for, anhydrite, gypsum and anglesite, $S_{\text {Anh }}$, S I $\quad \mathrm{Gp}_{\text {and }} \mathrm{SI}_{\mathrm{Ang}}$ are defined as $\log \left(\left(\mathrm{SO}_{4}^{2-}\right)\left(\mathrm{Ca}^{2+}\right) / \mathrm{Ksp}_{\mathrm{Anh}}\right), \log \left(\left(\mathrm{SO}_{4}^{2-}\right)\left(\mathrm{Ca}^{2+}\right)\left(\mathrm{H}_{2} \mathrm{O}\right)^{2} / \mathrm{Ksp}_{\mathrm{Gp}}\right)$ and $\log \left(\left(\mathrm{SO}_{4}^{2-}\right)\left(\mathrm{Pb}^{2+}\right) / \mathrm{Ksp}_{\text {Ang }}\right)$, respectively; where $\left(\mathrm{SO}_{4}^{2-}\right)$, $\left(\mathrm{Ca}^{2+}\right),\left(\mathrm{Pb}^{2+}\right)$ and $\left(\mathrm{H}_{2} \mathrm{O}\right)$ are the activities of $\mathrm{SO}_{4}^{2-}, \mathrm{Ca}^{2+}, \mathrm{Pb}^{2+}$ and water $(=1)$ in the aqueous solution, respectively. $\mathrm{SI}=0$ reflects equilibrium, $\mathrm{SI}<0$, undersaturation and $\mathrm{SI}>0$ supersaturation. These plots do not include Sls corresponding to other solid phases containing $\mathrm{Pb}$, such as plattnerite $\left(\mathrm{PbO}_{2}\right)$ and $\mathrm{Pb}(\mathrm{OH})_{2}$, because the system remains undersaturated with respect to them all along the interaction process. Plots in Fig. 8 show similar SIs evolutions for the aqueous solution with $\left[\mathrm{Pb}_{\mathrm{aq}}\right]_{0}=1000,100$ and $50 \mathrm{mg} / \mathrm{L}$. When the experiment starts, the solution contains no $\mathrm{Ca}^{2+}$ or $\mathrm{SO}^{2-}$ ions ${ }_{4}$ and is undersaturated $(\mathrm{SI}<0)$ with respect to any of the solid phases considered. The release of $\mathrm{Ca}^{2+}$ and $\mathrm{SO}^{2-}$ ions due to anhydrite dissolution readily determines a rapid increase of $\mathrm{SI}_{\mathrm{Anh}}, \mathrm{S} \mathrm{I}_{\mathrm{Gp}}$ and $\mathrm{SI}_{\text {Ang }}$ (see Fig. $8 \mathrm{~B}-\mathrm{C}$ ). This increase is especially rapid for $\mathrm{SI}_{\text {Ang, which }}$ reaches a maximum value few minutes after the beginning 


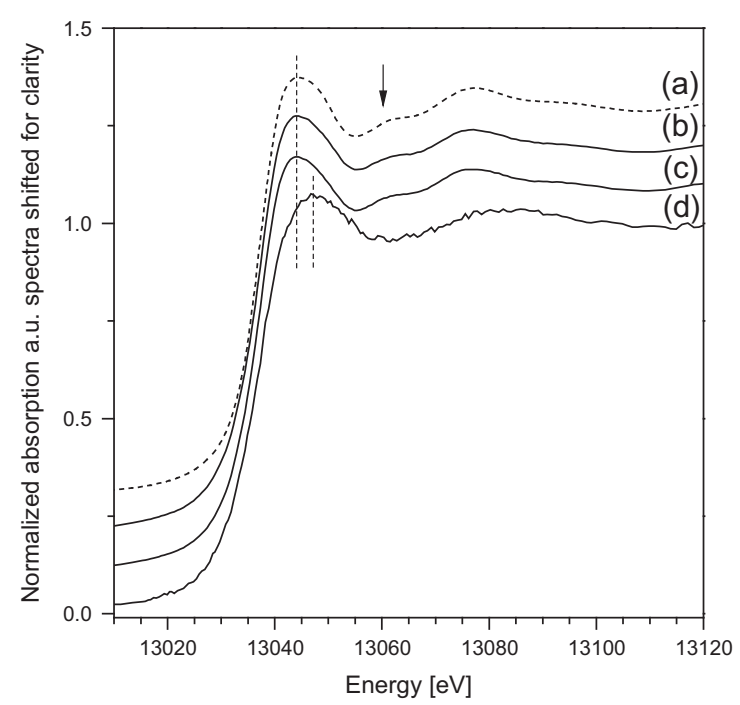

Fig. 5. $\mathrm{Pb} \mathrm{L}_{3}$-edge XANES spectra recorded on anhydrite $\left(\begin{array}{lll}0 & 0 & 1\end{array}\right)$ and $\left(\begin{array}{ll}1 & 00\end{array}\right)$ surfaces after $2 \mathrm{~h}$ interaction with aqueous solution containing $1000 \mathrm{mg} / \mathrm{L} \mathrm{Pb}((\mathrm{b})$, (c) respectively) and on anhydrite $\left(\begin{array}{lll}0 & 0 & 1\end{array}\right)$ surface after interacting during 1 week with an aqueous solution containing $10 \mathrm{mg} / \mathrm{L} \mathrm{Pb}$ (d) compared to a $\mathrm{PbSO}_{4}$ reference spectrum ((a), and dashed). Spectra of the $1000 \mathrm{mg} / \mathrm{L} \mathrm{Pb}$ runs are similar to the $\mathrm{PbSO}_{4}$ reference spectrum with respect to their whiteline positions (first vertical dashed line) and shape (hump indicated by arrow) whereas the spectrum from the diluted run is shifted about $3.2 \mathrm{eV}$ towards higher energy (second vertical dashed line) and the indicated hump is absent.

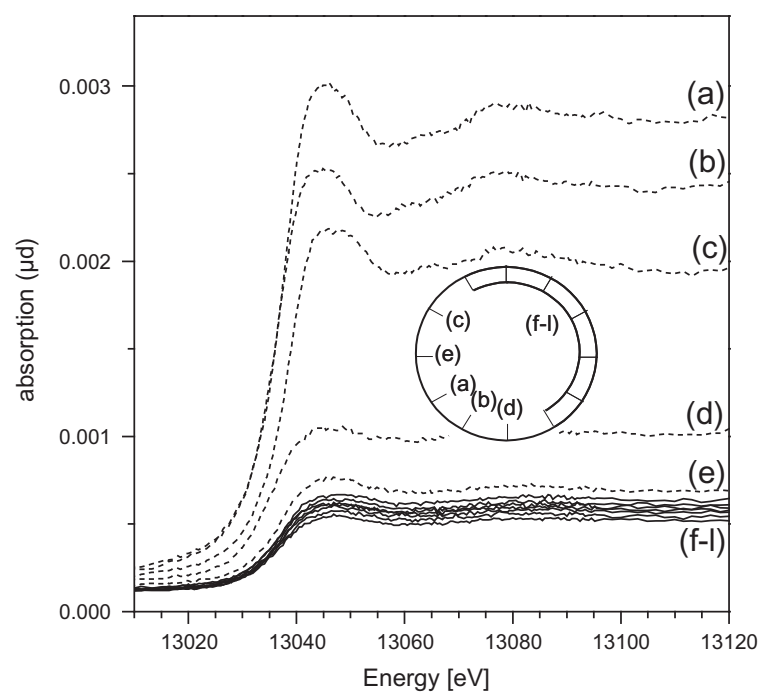

Fig. 6. $\mathrm{Pb} \mathrm{L}_{3}$-edge XANES spectra recorded on anhydrite $\left(\begin{array}{ll}0 & 01\end{array}\right)$ surface after interacting during 1 week with an aqueous solution containing $10 \mathrm{mg} / \mathrm{L} \mathrm{Pb}$ for different rotation angles around the normal to the sample surface. Seven spectra $((f)-(I))$ of almost the same but low fluorescence intensity and identical shape cover $180 \square$ of the $360 \square$ angular range whereas five spectra differ in shape and edge position and show higher fluorescence intensities (dashed lines, (a)-(e)). The inlet demonstrates the angular distribution of the spectra types.

of the interaction. $\mathrm{SI}_{\text {Ang }}$ subsequently decreases, rapidly dropping to values close to saturation $24 \mathrm{~h}$ after the beginning of the experiment. This drop is the direct consequence of the formation of anglesite, which removes $\mathrm{Pb}^{2+}$ and $\mathrm{SO}_{4}^{2-}$ ions from the solution.

The Sls with respect to gypsum and anhydrite increase very rapidly during the very early stage of the interaction (first $4 \mathrm{~h}$ ), at a slower rate subsequently, to finally reach a maximum value approximately 7 days after the beginning of the experiment. This maximum corresponds to $\mathrm{SI}_{\mathrm{Gp}}$ values slightly above 0 and $\mathrm{SI}_{\mathrm{Anh}}$

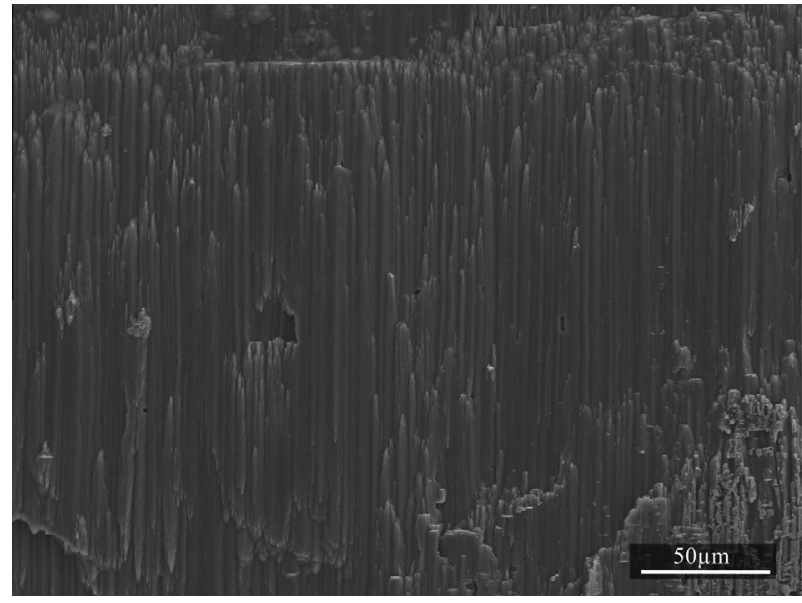

Fig. 7. Scanning electron micrographs of a partially dissolved anhydrite $(001)$ surface showing typical grooves regularly oriented parallel to [100].

values significantly below 0 . From this point, $\mathrm{SI}_{\mathrm{Gp}}$ and $\mathrm{SI}_{\mathrm{Anh}}$ slowly decrease to reach a steady state. This steady state is characterized by a $\mathrm{SI}_{\mathrm{Gp}}$ value very close to 0 , but corresponding to a small supersaturation of the solution with respect to this phase. The slight supersaturation reached by the system with respect to gypsum after 1 week of interaction explains the formation of gypsum crys-tals on the surface of anhydrite after long interaction times (see Fig. 3b). It is noteworthy that the amount of gypsum observed in-creases as the interaction progresses. This can be explained as due to the development of the solvent mediated transformation of anhydrite into gypsum. This solvent mediated transformation in-volves the coupled dissolution of anhydrite and the crystallization of gypsum and becomes the predominant process in the system after $\mathrm{SI}_{\text {Ang }}$ has dropped to saturation and most $\mathrm{Pb}_{\mathrm{aq}}$ has been removed.

The evolution of aqueous solution Sls with respect to anglesite, anhydrite and gypsum when $\left[\mathrm{Pb}_{\mathrm{aq}}\right]_{0}=10 \mathrm{mg} / \mathrm{L}$ is shown in Fig. $8 \mathrm{~d}$. In this case, $\mathrm{SI}_{\text {Ang }}$ reached a maximum 60 min after the beginning of the interaction. This maximum was, however, much lower than in the previous cases, with a value $\sim 0.46$. Beyond this point the $\mathrm{SI}_{\text {Ang }}$ slowly decreased to reach a value close to saturation after $\sim 3$ weeks.

The dissolution-precipitation mechanisms involves the release of $\mathrm{Ca}^{2+}$ and $\mathrm{SO}^{2} \overline{4}$ ions from the anhydrite surface to the aqueous

solution and the subsequent reaction of the dissolved $\mathrm{SO}_{4}^{2-}$ ion with the aqueous $\mathrm{Pb}^{2+}$ present in the solution, leading to the nucle-ation and growth of $\mathrm{PbSO}_{4(\mathrm{~s})}$. Thus, both processes, anhydrite dis-solution and anglesite surface precipitation, are coupled, defining a coprecipitation sorption mechanism. Although co-precipitation seems to be the main mechanism operating in the anhydrite sur-faces, other mechanisms must play a role when low $\mathrm{Pb}$ concentra-tions are used. These mechanisms can include adsorption or even solid-state diffusion into the crystal. In the case of gypsum crystals interacting with $\mathrm{Pb}$-bearing solutions, Astilleros et al. (2010) found that when the concentration of $\mathrm{Pb}$ was low $\left(\left[\mathrm{Pb}_{\mathrm{aq}}\right]_{0}=10 \mathrm{mg} / \mathrm{L}\right), \mathrm{Pb}$ removal most probably occurred through adsorption mechanisms, according to the results of Rutherford Backscattered Spectroscopy (p-RBS) measurements. In the case of the interaction between anhydrite and low $\mathrm{Pb}$-concentrated aqueous solutions $\left(\left[\mathrm{Pb}_{\mathrm{aq}}\right]_{0}=10 \mathrm{mg} / \mathrm{L}\right)$ anglesite could not be detected by SEM imagin-ing of anhydrite surfaces. Moreover, XANES spectra collected on the main anhydrite cleavage surfaces, $\left(\begin{array}{lll}1 & 0 & 0\end{array}\right),\left(\begin{array}{ll}01 & 0\end{array}\right)$, and (001) after interaction with low Pbconcentrated solutions during 1 week did not match the characteristics of that of the anglesite reference. These results point to other sorption processes than 

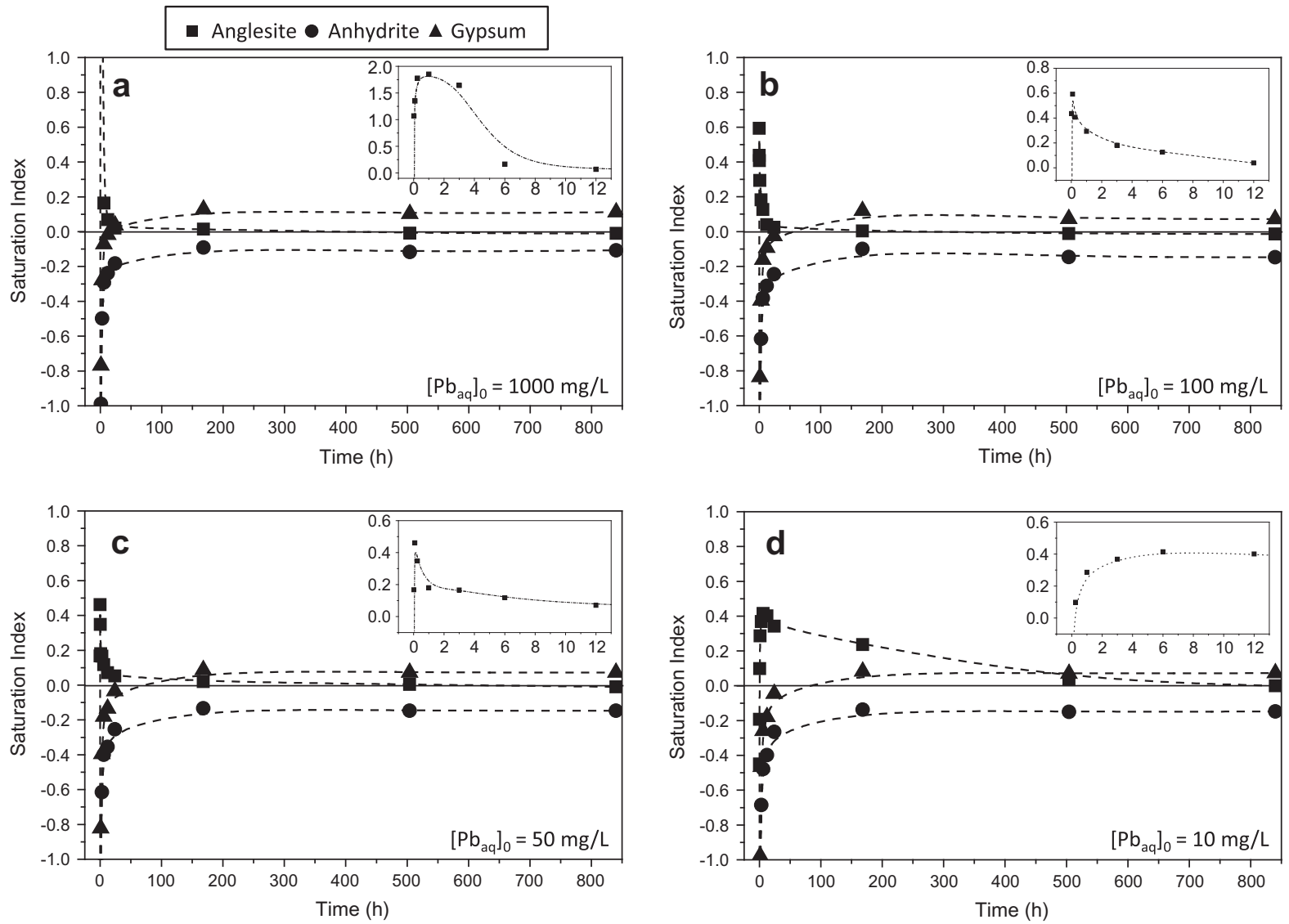

Fig. 8. Evolution of SIs of the aqueous solutions with respect to anhydrite, gypsum and anglesite as a function of time. The data correspond to the interaction of anhydrite fragments with different Pb-bearing solutions (a) $1000 \mathrm{mg} / \mathrm{L}$, (b) $100 \mathrm{mg} / \mathrm{L}$, (c) $50 \mathrm{mg} / \mathrm{L}$, and (d) $10 \mathrm{mg} / \mathrm{L}$.

co-precipitation as responsible for $\mathrm{Pb}$ removal also in the case of anhydrite.

The ability and effectiveness of anhydrite to uptake $\mathrm{Pb}$ from aqueous solutions $\left(\left[\mathrm{Pb}_{\mathrm{aq}}\right]_{\infty} \approx 3 \mathrm{mg} / \mathrm{L}\right)$ is similar to that showed by gypsum. In principle, and taking into account physicochemical parameters only, this result is reasonable because both minerals are compositionally equivalent and have very close solubility prod-ucts at $25^{\circ} \mathrm{C}$. Indeed, in both cases the final $\mathrm{Pb}$ concentration in the solution seems to be controlled by the solubility of anglesite, since after prolonged interaction times saturation with respect to this phase is always achieved. However, this is not necessarily the ex-pected conclusion if the spatial arrangement (epitactic relation-ships) of the anglesite crystals on the anhydrite surfaces is taken into consideration. As explained above, several authors have previously stated that the existence of crystallographic relation-ships between sorbant and sorbate constitute a critical factor which can dramatically reduce the capability of a mineral to re-move a pollutant (Prieto et al., 2002, 2003; Rodríguez-Blanco et al., 2007). Surprisingly, the existence of epitactic relationships between anglesite and anhydrite (Fig. 2) and the lack of these rela-tionships between anglesite and gypsum do not introduce any sig-nificant difference in the $\mathrm{Pb}$ removal kinetics when these $\mathrm{CaSO}_{4}$ phases are used. The explanation for anhydrite surfaces remaining capable to remove $\mathrm{Pb}$ after the epitactic formation of anglesite crystals results from the combination of a number of factors. First, anglesite crystals are micrometer-sized and show a 3D tabular to blocky habit. For the anhydrite substrate being armored from the fluid these $3 D$ crystals would have to coalesce to form a microme-ter-thick anglesite layer, which would require the uptake of an amount of $\mathrm{Pb}_{(\mathrm{aq})}$ several orders of magnitude higher than if this layer were nanometer-thick as is the case of the otavite layer formed on calcite surfaces as a result of Cd sorption. Second, the adhesion of anglesite onto anhydrite is relatively weak, which pro-motes the detachment of a great volume of anglesite crystals from the anhydrite surface as a result of friction forces arising from the stirring during the experiment. Third, contrary to calcite frag-ments, which frequently are

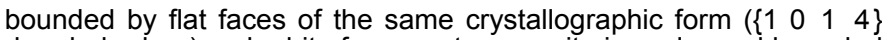
rhombohedron), anhydrite frag-ments are quite irregular and bounded by flat surfaces belonging to different forms. The reactivity of fragments with such character-istics is extremely anisotropic: whereas some surfaces can be pro-fusely covered by anglesite crystals, others can remain almost free of crystals. Indeed, synchrotron $\mu$-XRF maps evidence a non-homo-geneous distribution of $\mathrm{Pb}$ on anhydrite surfaces, with anglesite nucleation being strongly affected by the degree of roughness on different areas, which in turn determines that the flatter regions on anhydrite surfaces remain always available to the interaction with the solution.

\section{Conclusions}

The results obtained in this work confirm that anhydrite surfaces remove $\mathrm{Pb}$ from aqueous solutions as efficiently as gypsum surfaces. Moreover, Pb-uptake by anhydrite involves two mechanisms: (a) anglesite precipitation coupled to substrate dissolution, which is the mechanism predominant when the concentration of $\mathrm{Pb}$ is higher than $50 \mathrm{mg} / \mathrm{L}$, and (b) adsorption, which mainly oper-ates at low $\mathrm{Pb}$ concentrations. It is noteworthy that, although anglesite crystals grow oriented on anhydrite surfaces, contrarily 
to the observations reported for other systems, the existence of epitaxial relationships between both phases does not affect the capacity of anhydrite as a Pb-remover. The high reactivity of anhydrite surfaces in contact with $\mathrm{Pb}$-bearing aqueous solutions suggests that this phase can potentially play a role in controlling the fate of this pollutant in the Earth crust. Although a final Pb concentration value of $\sim 3 \mathrm{mg} / \mathrm{L}$ is still far away from the quality parameters of the EC Drinking Water Directive (98/83/ECC) or the WHO (10 $\mu \mathrm{lg} / \mathrm{L})(\mathrm{Gray}, 2008)$, anhydrite can naturally attenuate the amount of $\mathrm{Pb}$ in natural waters and the interaction between anhydrite and $\mathrm{Pb}$-bearing aqueous solution has enough potential-ity

to be considered an initial step in Pb-removal strategies involving sequences of fluid-mineral reactions.

\section{Acknowledgements}

We acknowledge the Synchrotron Light Source ANKA for provision of beamtime at the SUL-X beamline within the proposal ENV-216. This research was supported by MICINN-Spain, under Grant CGL2010-20134-C02-01 and -2. J. Morales acknowledges a FPI fellowship from the Spanish MICINN.

\section{References}

ANKA Instrumentation Book, 2011. Karlsruhe Institute of Technology, EggensteinLeopoldshafen, Germany, $111 \mathrm{~S}$.

Astilleros, J.M., Godelitsas, A., Rodríguez-Blanco, J.D., Fernández-Díaz, L., Prieto,

M., Lagoyannis, A., Harissopulos, S., 2010. Interaction of gypsum with Pb - bearing aqueous solutions. Appl. Geochem. 25, 1008-1016.

Freyer, D., Voigt, W., 2003. Crystallization and phase stability of $\mathrm{CaSO}_{4}$ and

CaSO4-based salts. Monatsh. Chem. 134, 693-719.

Godelitsas, A., Astilleros, J.M., 2010. Dissolution, sorption/(re)precipitation, formation of solid solutions and crystal growth phenomena on mineral surfaces: implications for the removal of toxic metals from the environment. In Prieto, M., Stoll, H. (Eds.), Ion Partitioning in Ambient-Temperature Aqueous Systems. EMU Notes in Mineralogy 10. European Mineralogical Union and the Mineralogical Society of Great Britain \& Ireland, London, pp. 289-324.
Gray, N.F., 2008. Drinking Water Quality: Problems and Solutions, second ed. Cambridge University Press, Cambridge, UK.

Hodson, M.E., Valsami-Jones, E., Cotter-Howells, J.D., 2000. Metal phosphates andremediation of contaminated land. In: Cotter-Howells, J.D., Campbell, L.S. Valsami-Jones, E., Batchelder, M. (Eds.), Environmental Mineralogy: Microbial Interactions, Anthropogenic Influences, Contaminated Land and Waste Management. Mineralogical Society of Great Britain \& Ireland, London, pp. 291311.

Morales, J., Astilleros, J.M., Fernández-Díaz, L., Álvarez-Lloret, P., Jiménez, A., 2013. Anglesite $\left(\mathrm{PbSO}_{4}\right)$ epitactic overgrowths and substrate-induced twinning on anhydrite (CaSO4) cleavage surfaces. J. Cryst. Growth 380, 130-137.

O'Day, P., Vlassopoulos, D., 2010. Mineral-based amendments for

remediation. Elements 6, 375-381

Parkhurst, D.L., Appelo, C.A.J., 1999. User's Guide to PHREEQC (Version 2) - A Computer Program for Speciation, Batch-Reaction, One-Dimensional Transport and Inverse Geochemical Calculations (US Geological Survey. WaterResources Investigations, Report 1999, 99-4259).

Pérez-Garrido, C., Fernández-Díaz, L., Pina, C.M., Prieto, M., 2007. In situ AFM observations of the interaction between calcite $\mathrm{f} 10 \mathrm{14 \textrm {g }}$ surfaces and $\mathrm{Cd}$ bearing aqueous solutions. Surf. Sci. 601, 5499-5509.

Pérez-Garrido, C., Astilleros, J.M., Fernández-Díaz, L., Prieto, M., 2009. In situ

AFM study of the interaction between calcite (1014) surface and supersaturated $\mathrm{Mn}^{2 \mathrm{P}}-\mathrm{CO}^{2}-$ aqueous solutions. J. Cryst. Growth $311,4730-4739$.

Prieto, M., Fernán ${ }^{3}$ dez-González, A., Martín-Díaz, R., 2002. Sorption of chromate ions diffusing through barite-hydrogel composites: implications for the fate and transport of chromium in the environment. Geochim. Cosmochim. Acta 66, 783-795.

Prieto, M., Cubillas, P., Fernández-González, A., 2003. Uptake of dissolved Cd by biogenic and abiogenic aragonite: a comparison with sorption onto calcite. Geochim. Cosmochim. Acta 67, 3859-3869.

Prieto, M., Astilleros, J.M., Fernández-Díaz, L., 2013. Environmental remediation by crystallization of solid solutions. Elements 9, 195-202.

Ravel, B., Newville, M., 2005. Athena, Artemis, Hephaestus: data analysis for X-ray absorption spectroscopy using IFEFFIT. J. Synchrotron Rad. 12, 537-541.

Rodríguez-Blanco, J.D., Jiménez, A., Prieto, M., 2007. Oriented overgrowth

of pharmacolite $\left(\mathrm{CaHAsO}_{4} \cdot 2 \mathrm{H}_{2} \mathrm{O}\right)$ on gypsum $\left(\mathrm{CaSO} 4 \cdot 2 \mathrm{H}_{2} \mathrm{O}\right)$. Cryst. Growth Des. 7, 2756-2763.

Sharpe, R., Cork, G., 2006. Gypsum and anhydrite. In: Kogel, J.E., Trivedi, N.C.,

Barker, .M., ru ows I, S.T. (Eds.), Industrial Minerals Rocs Commodities, Markets, and Uses. Society for Minning, Metallurgy and Exploration Inc., Colorado, USA, pp. 519-540.

Tucker, M.E., 2001. Sedimentary Petrology: An Introduction to the Origin of Sedimentary Rocks, third ed. Wiley-Blackwell. 